\title{
Formulation and production of a blood-free and chemically defined virus production media for VERO cells
}

\author{
Randall Alfano ${ }^{1}$, Atherly Pennybaker ${ }^{2}$, Peter Halfmann ${ }^{3}$, and Claire Huang ${ }^{4}$ \\ ${ }^{1}$ Ventria Bioscience \\ ${ }^{2}$ InVItria \\ ${ }^{3}$ University of Wisconsin System \\ ${ }^{4}$ Centers for Disease Control and Prevention
}

April 28, 2020

\begin{abstract}
Vaccines provide effective protection against many infectious diseases as well as therapeutics for some serious diseases, such as cancer. Many viral vaccines require amplification of virus in cell cultures during manufacture. Traditionally, cell cultures, such as VERO, have been used for virus production in bovine serum-containing culture media. However, due to concerns of potential adventitious agents present in fetal bovine serum (FBS), regulatory agencies suggest avoiding the use of bovine serum in vaccine production. Current serum-free media suitable for VERO-based virus production contains high concentrations of undefined plant hydrolysates. Although these media have been extensively used, the lack of chemical definition has potential to adversely affect cell growth kinetics and subsequent virus production. As plant hydrolysates are made from plant raw materials, performance variations could be significant among different lots of production. We developed a chemically defined, serumfree medium, OptiVERO, that was optimized specifically for VERO cells. VERO cell growth kinetics were demonstrated to be equivalent to EMEM-10\% FBS in this chemically defined medium while the plant hydrolysate-containing medium demonstrated a higher doubling time in both 2D and 3D cultures. Virus production comparisons demonstrated that the chemically defined OptiVERO medium performed at least as good as the EMEM-10\%FBS and better than the plant hydrolysate-containing media. We report the success in using recombinant proteins to replace undefined plant hydrolysates to formulate a chemically defined medium that can efficiently support VERO cell expansion and virus production.
\end{abstract}

\section{Hosted file}

OptiVERO Manuscript FINAL Biotechnology and Bioengineering.pdf available at https://authorea. com/users/307773/articles/438742-formulation-and-production-of-a-blood-free-and-chemicallydefined-virus-production-media-for-vero-cells 